\title{
R. V. IMPERIAL TOBACCO LTD.: More Restrictions on Public Authority Tort Liability
}

\author{
LEWIS N. KLAR, Q.C.*
}

\section{INTRODUCTION}

Since 2001, it has become very difficult for claimants to successfully sue public authorities for their negligent conduct, particularly in relation to their regulatory functions. This primarily has been due to the refined duty of care formula established by the Supreme Court of Canada in Cooper v. Hobart ${ }^{1}$ and Edwards v. Law Society of Upper Canada. ${ }^{2}$

R. v. Imperial Tobacco $L t d .^{3}$ represents the latest unsuccessful attempt to hold a government liable for its alleged negligence, this time in relation to the manner in which the Government of Canada regulated the tobacco industry. In its judgment, the Supreme Court of Canada focused on three matters which I would like to discuss in this commentary. First, the Court reaffirmed its approach to the establishment of a duty of care in negligence actions in general. Second, the Court revisited the law relating to negligent misrepresentation cases. Third, the Court refined the "policy/operational” dichotomy long used by Canadian courts to limit the liability of public authorities.

As a result of this judgment, the Supreme Court of Canada has restricted even further the ability of private claimants to successfully sue governments for their regulatory failures.

\section{THE LitigATION}

Two separate principal actions and several claims for contribution are involved in this litigation. In British Columbia v. Imperial Tobacco Canada Ltd. ${ }^{4}$ (known as the Cost Recovery case), Imperial Tobacco and 13 other tobacco companies were sued by the Province of British Columbia for the health care costs related to the treatment of individuals suffering from tobacco-related illnesses. These claims were brought pursuant to the Tobacco Damages and Health Care Costs Recovery Act. ${ }^{5}$ In the second action, Knight v. Imperial Tobacco Canada Ltd., ${ }^{6}$ Imperial Tobacco was sued by a class of consumers for a refund of the costs of low tar cigarettes purchased by them. This action was brought pursuant to the British Columbia Business Practices and Consumer Protection $\mathrm{Act}^{7}$ and its predecessor, the Trade Practice Act. ${ }^{8}$

\footnotetext{
Professor, Faculty of Law, University of Alberta. This comment is based upon a presentation made at the 8th Annual Conference on Crown Liability, Osgoode Professional Development, Toronto, 17 February 2012.

2001 SCC 79, [2001] 3 SCR 537 [Cooper].

2001 SCC 80, [2001] 3 SCR 562 [Edwards].

2011 SCC 42, [2011] 3 SCR 45 [Imperial Tobacco].

2003 BCSC 877, 277 DLR (4th) 323 [Cost Recovery].

SBC 2000, c 30. The constitutionality of this legislation was affirmed by the Supreme Court of Canada in British Columbia v Imperial Tobacco Canada Ltd, 2005 SCC 49, [2005] 2 SCR 473.

6 Certified as a class proceeding 2005 BCSC 172, 250 DLR (4th) 347, varied in part 2006 BCCA 235, 267 DLR (4th) 579 [Knight].

SBC 2004, с 2.

RSBC 1996, c 457.
} 
Third party claims for contribution were brought by the defendant tobacco companies against the Government of Canada in both actions. The claims alleged that the Government of Canada was liable to consumers of low tar cigarettes and to the tobacco company defendants for negligent misrepresentations, negligent design and development of the tobacco products, and failure to warn of the health hazards of smoking low tar cigarettes. The claims for contribution were based on the British Columbia Negligence Act, ${ }^{9}$ as well as on the direct liability of the Government of Canada to the tobacco companies. Other claims that were made related to the doctrine of "equitable indemnity" and the statutory liabilities of the Government of Canada under the above noted legislative provisions. These other claims lie outside the scope of this commentary and will not be discussed.

The claims for contribution were struck out in their entirety by Justice Satanove in the Knight case. ${ }^{10}$ On appeal to the British Columbia Court of Appeal, the judgment was varied and the negligent misrepresentation claims, as well as the negligent development claim, were allowed to proceed. ${ }^{11}$ The claims for contribution were also struck out in their entirety in the Cost Recovery case by Justice Wedge. ${ }^{12}$ On appeal, the majority of the British Columbia Court of Appeal allowed the negligent misrepresentation claim to proceed. ${ }^{13}$

The Government of Canada appealed to the Supreme Court of Canada, seeking the striking out of all claims, and the tobacco companies cross appealed, asking that all claims be allowed to proceed. The Government of Canada was successful and all contribution claims were struck out.

\section{Establishing a DUTy OF CARE in Negligence CASES}

\section{A. INTRODUCTION}

The refined duty formula established in Cooper and Edwards is used to establish a duty of care in negligence cases in Canada. The three elements of the duty formula are foreseeable harm to the plaintiff, proximity between the parties, and consideration of residual policy concerns. The duty formula is said to be applicable to "novel" disputes, meaning those disputes which do not fall into categories of duty that previously have been recognized, or categories analogous to recognized categories. Where statutory authorities are involved, proximity between the parties is said to be found either in the provisions of the statutes that empower the authorities, or in the relationships or interactions that existed between the parties. All of this is well known. What, then, did the Supreme Court of Canada tell us in Imperial Tobacco that we did not know?

RSBC 1996, с 333.

See Knight $v$ Imperial Tobacco Canada Ltd, 2007 BCSC 964, [2008] 4 WWR 156.

Knight v Imperial Tobacco Canada Ltd, 2009 BCCA 541, 313 DLR (4th) 695. Justice Hall dissented and would have struck out all the claims. The Court of Appeal's reasons for striking out the "negligent design" claim were interesting as they focused on the jurisprudence relating to recovery for "relational economic losses.” The claim was struck out due to the policy concern for "indeterminate liability.” In my opinion, describing these as "relational economic losses" was an unusual approach to this issue. See British Columbia v Imperial Tobacco Canada Ltd, 2008 BCSC 419, 292 DLR (4th) 353.

British Columbia v Imperial Tobacco Canada Ltd, 2009 BCCA 540, 313 DLR (4th) 651 (Hall JA, dissenting) [Imperial Tobacco (BCCA)]. 


\section{B. WHAT IS A RECOGNIZED CATEGORY?}

It has become increasingly clear that determining whether a dispute before the court is a novel one or falls into a recognized duty category is a highly arbitrary exercise. This observation is borne out by Imperial Tobacco, as well as by other recent judgments.

Although the action for a negligent statement was explicitly recognized by the Supreme Court of Canada as a recognized duty category in Cooper, and despite the fact that claims for negligent misrepresentation were being advanced in Imperial Tobacco, Chief Justice McLachlin held that these claims did not fall "within a settled category of negligent misrepresentation" since "[t]he law of negligent misrepresentation has thus far not recognized liability in the kinds of relationships at issue in these cases." ${ }^{14}$ Chief Justice McLachlin reasoned that the tobacco companies could not point to any case "where a government has been held liable in negligent misrepresentation for statements made to an industry." 15 Thus, this case represented a new category of negligent statement disputes, and required a full Cooper analysis.

The judgment illustrates the difficulty which courts and counsel face in determining whether the dispute before them is a novel or recognized category. Courts seemingly can go either way in deciding this; it tends to be a result-oriented decision. Where a court wishes to justify a finding that there is a duty of care based upon analogies to a recognized duty category, it will do so, even if on the surface the disputes seem very different. For example, in Fullowka v. Pinkerton's of Canada Ltd., ${ }^{16}$ Justice Cromwell drew a parallel between the earlier negligent building inspection cases and the dispute in Fullowka, which involved the failure of mining safety inspectors to protect miners against the criminal act of Roger Warren. In the New Brunswick Court of Appeal decision in Adams v. Borrel, ${ }^{17}$ the negligence of government officials regarding the investigation of a potato virus was analogized to the pre-Cooper building inspection and road maintenance cases. The same argument was rejected, however, in the Los Angeles Salad Company v. Canada Food Inspection Agency ${ }^{18}$ judgment, where the negligent regulation of contaminated food products was held not to fall into a recognized duty category.

Attempting to categorize disputes by reference to novel or recognized categories has not been a helpful exercise. More significantly, Canadian negligence law has moved decidedly away from Lord Atkin's “neighbour principle,” which created a general formula of duty applicable to all disputes, toward the fragmentation of negligence law into discrete duty categories, reminiscent of pre-Donoghue v. Stevenson ${ }^{19}$ law. It increasingly appears that new factual disputes will be viewed by Canadian courts as new duty of care categories, subject to a full Cooper analysis in almost all cases. Counsel should, therefore, be prepared to deal with foreseeability, proximity, and residual policy in their negligence law cases. 


\section{FORESEEABILITY OF HARM}

The "foreseeability" element of the duty formula is an ambiguous concept. As foreseeability is a factor considered by the courts in determining duty, breach of duty, and remoteness of injury, there tends to be confusion in the case law of how and where it is best dealt with. It is also arguable that in view of the requirement of "proximity" as a supplement to foreseeability, the foreseeability element itself has become superfluous. ${ }^{20}$

Although foreseeability of harm was not a major issue in Imperial Tobacco, it was nevertheless raised. The Government of Canada in the Cost Recovery case argued that harm to the third party claimants, the tobacco companies, was not reasonably foreseeable by the Government of Canada: it was not reasonably foreseeable that new legislation would be enacted by the Government of British Columbia which would require tobacco companies to pay for the health care costs related to cigarette smoking. Thus, even if Canada had been negligent in some way with respect to the tobacco companies, it was not foreseeable that this negligence would result in the tobacco companies having to pay the health care costs of smokers. Although this argument was accepted by Appeal Justice Hall, it was rejected by the Supreme Court of Canada. Chief Justice McLachlin stated that as long as there was foreseeability of harm "of some sort," the element of foreseeability would be satisfied. ${ }^{21}$ All that is required is the foreseeability of harm "in a general way," not necessarily the specific harm that occurred. ${ }^{22}$

\section{THE ISSUE OF “PROXIMITY”}

For a presumptive duty of care to exist at stage one of the two stage duty test, the new formula requires that there had been not only a reasonably foreseeable risk of harm to the plaintiff, but also "proximity" between the parties. In this respect, the search for proximity between claimants and public authorities largely has focused on the statutory provisions which empower the authorities and define their responsibilities. Since it has become clear that statutes which establish authorities and give them responsibilities to protect the public at large generally cannot be interpreted to create private common law rights of action, proximity between the parties rarely has been found. Thus, actions against public authorities based on a search for proximity within the provisions of a statute invariably have been dismissed. Although courts have agreed that proximity also can be found in the relationship and interactions which occurred between the parties and have begun to look there for proximity, this has not, for the most part, improved the success rate of claimants suing government. $^{23}$

Prior to Anns v Merton London Borough Council, [1977] UKHL 4, [1977] 2 All ER 118 [Anns], courts were reluctant to deny duty based on "policy" grounds. Thus, the absence of foreseeable harm played the useful role to deny a duty as a matter of law, even if the real reason for the denial of duty was judicial "policy." Now that policy concerns, concerns of "justice" and "fairness," and even concerns regarding the "effect on society" if a duty were recognized determine the issue of duty, the need to deny duty based on lack of "foreseeability" has disappeared.

Imperial Tobacco, supra note 3 at para 57.

Ibid, citing Imperial Tobacco (BCCA), supra note 13 at para 78, Tysoe JA.

I have written about this issue elsewhere. My principal points have been that it is wrong for Canadian courts to attempt to interpret statutes to find proximity, that if they do they will not find it, and that the only place to look for proximity is in the relationships which existed between the parties. I believe that this analysis is consistent with Canadian law relating to beach of statute established by the Supreme Court of Canada in Canada v Saskatchewan Wheat Pool, [1983] 1 SCR 205 [Sask Wheat Pool], is a 
The tobacco companies alleged that the Government of Canada had negligently misrepresented to both consumers and the tobacco industry the health benefits to smokers who switched to low tar cigarettes. They also alleged that the Government of Canada was negligent in failing to warn consumers and the tobacco industry about the hazards of low tar cigarettes, and in failing to design the tobacco strain with due care. The argument was that these misrepresentations, its failure to warn, and the negligent design breached duties of care owed by the government to both the consumers of cigarettes and to the industry defendants. Did the Government of Canada owe a duty of care to either the consumers or the tobacco industry with regard to any of this alleged misconduct? Was there proximity between the Government of Canada and the consumers of cigarettes or the tobacco industry?

Consistent with the post-Cooper jurisprudence, the Court looked to the governing statutes to determine whether they created proximity between the parties. ${ }^{24}$ Consistent with almost all of the jurisprudence since Cooper, the Court held that the statutes established "only general duties to the public, and no private law duties to consumers."25 While the Court maintained its Cooper approach that statutes can be the source of proximity for the purpose of a private law duty of care, and that courts can "infer that the legislature intended to create private tort law duties to claimants," the Court conceded that "[i]t may be difficult to find ... a statute [that] creates sufficient proximity to give rise to a duty of care," because "more often, statutes are aimed at public goods, like regulating an industry (Cooper), or removing children from harmful environments (Syl Apps)." ${ }^{26}$ While this is, at least to me, a step in the right direction in moving courts away from statutory interpretation in order to find private law duties of care, it must be underscored that the Supreme Court has not abandoned its approach. However, the Court has admitted that this route is unlikely to be successful. ${ }^{27}$

Having rejected the statutes as the source of proximity, the Court then turned to the interactions which existed between the parties. Were there "specific interactions" between the Government of Canada and consumers of cigarettes, or between the Government of Canada and the tobacco companies that could give rise to proximity? Recall that because this was a motion to strike, the Court accepted the facts as pleaded to be true. Thus, the Court accepted that Canada represented to consumers and to tobacco companies that light cigarettes were less harmful, that these representations were not accurate, and that both the consumers

correct understanding of what "proximity" means, and is the only approach that can result in a favourable outcome for claimants. See Lewis Klar, QC, "Tort Liability of the Crown: Back to Canada v. Saskatchewan Wheat Pool” (2007) 32:3 Advocates’ Q 293; Lewis Klar, “Syl Apps Secure Treatment Centre v. B.D.: Looking for Proximity within Statutory Provisions” Case Comment (2007) 86:2 Can Bar Rev 337; Lewis N Klar, "Breach of Statute and Tort Law" in Jason W Neyers, Erika Chamberlain \& Stephen GA Pitel, eds, Emerging Issues in Tort Law (Portland: Hart, 2007) 31; Lewis Klar, "The Tort Liability of Public Authorities: The Canadian Experience” in Torts in Commercial Law, Simone Degeling, James Edelman \& James Goudkamp, eds (Pyermont, NSW: Thomson Reuters Australia, 2011) 243. Also see Lewis N Klar, QC, Tort Law, 4th ed (Toronto: Thomson Canada, 2008). Department of Health Act, SC 1996, c 8; Department of Agriculture and Agri-Food Act, RSC 1985, c A-9; Tobacco Act, SC 1997, c 13; Tobacco Products Control Act, SC 1988, c 20. Imperial Tobacco, supra note 3 at para 50.

Ibid at para 44 [emphasis added]. This type of language, which is used in many judgments, makes it clear that courts are not merely using statutes to support the existence of an independent common law duty, but are actually interpreting statutes to determine whether there was the legislative intent to create a private right of action. This is clearly contrary to Justice Dickson's judgment in Sask Wheat Pool, supra note 23, which cautions against the search for a "fictitious" and "non-existent" legislative intention.

27 Since the type of legislation at issue in Cooper, Edwards, and other similar cases have not been interpreted to be for the protection of private individuals, it is difficult to predict which ones will be. Clearly the purpose of the Mortgage Brokers Act, RSBC 1996, c 313, for example, was to protect the interests of those who invested with mortgage brokers, and not the public at large. 
and the tobacco companies relied and acted on them to their detriment. Were these interactions sufficient?

Looking first at the alleged duty owed by the Government of Canada to the consumers, Chief Justice McLachlin held that there were "no specific interactions between Canada and the class members" ${ }^{28}$ which could be used to establish proximity. Since (as noted above) the Court accepted, for the purposes of the motion to strike, that there were inaccurate representations made by the government to consumers and detrimental reliance on them, one must conclude that implicit in the Court's holding is that reliance on representations made by government which are reasonably and detrimentally relied upon by the public do not constitute "specific" interactions sufficient to establish proximity between the parties. There must be something more. There must be a "direct relationship.”

The government's duty to the tobacco companies was approached more favourably by the Court. The "history of interactions between Canada and the tobacco companies"29 that was pled by the third party claimants was capable of fulfiling the conditions necessary for proximity. These interactions included the advising and assisting of the companies in promoting and designing low tar cigarettes.

\section{E. THE REQUIREMENT OF A "SPECIAL RELATIONSHIP” IN NEGLIGENT STATEMENT CASES}

Imperial Tobacco is the first negligent statement case decided by the Supreme Court of Canada since Cooper. It was interesting to see, therefore, what impact the reformulated duty of care would have on these types of claims.

Prior to Cooper, the Canadian cases of Queen v. Cognos $^{30}$ and Hercules Managements Ltd. v. Ernst \& Young ${ }^{31}$ approached the duty issue in negligent statement cases in two stages. The first stage asked whether there was a "special relationship" between the parties. If the defendant ought to have reasonably foreseen that the plaintiff would rely upon the representations made, in circumstances when such reliance would be reasonable, there was a special relationship between the parties, giving rise to a prima facie duty of care. The courts did not consider proximity as a consideration separate from reasonably foreseeable reliance. The special relationship created the proximity. ${ }^{32}$ As explained by the Court in Imperial Tobacco, in negligent misrepresentation cases both requirements of foreseeability and proximity are established if there was a special relationship between the parties. ${ }^{33}$ This duty could then be negated by policy considerations at stage two of the analysis. In Hercules Managements, for example, there was a special relationship between the auditors of a company and investors, but the duty was negated by fears of indeterminate liability.

Imperial Tobacco, supra note 3 at para 49.

Ibid at para 52.

[1993] 1 SCR 87.

[1997] 2 SCR 165 [Hercules Managements].

Note as well that pre-Cooper there was no separate element of "proximity" as a supplement to foreseeability. Proximity was added to the formula by Cooper.

Supra note 3 at para 42 . 
I think it is fair to assume that in "ordinary" negligent statement cases, the Hercules Managements approach still prevails. As noted above, however, the Court treated the negligent statement claims in Imperial Tobacco as giving rise to a novel type of negligent statement case. Thus, rather than applying a straight-forward special relationship analysis to stage one of the two stage test to find proximity, ${ }^{34}$ the Court looked both to the legislation as well as to the specific interactions between the parties to determine whether a prima facie duty was owed. As pointed out above, the Court concluded that the statutes did not establish private law duties to consumers or to the tobacco companies. The Court then turned its attention to the interactions that occurred between the parties, and found that there were no interactions sufficient to create proximity between the government and consumers, although there was proximity between the government and the tobacco companies based upon their extensive and direct interactions.

The Court's treatment of the duty owed to consumers by the Government of Canada with respect to the negligent misrepresentations was particularly interesting. The Court accepted, for the purpose of the motion to strike, that the government did make inaccurate representations to consumers concerning the health benefits of low tar cigarettes and that these representations were relied upon by consumers to their detriment. The tobacco companies argued that the government could reasonably have foreseen this reliance and that this reliance was reasonable. Despite this, the Court rejected the contention that this gave rise to a duty. The reason for the Court's rejection of a duty was unfortunately quite brief. The Court simply said that the facts as pleaded established "no direct relationship" between Canada and the consumers. ${ }^{35}$ The statements were made to the general public. There were no specific interactions; there was no proximity. ${ }^{36}$

I believe that this finding has important implications for future negligence suits between private persons and government regulators based on allegations of negligent misrepresentations made and relied upon. Reliance on representations made by government to the general public concerning, for example, the safety of products, will be insufficient to create proximity. In the absence of pleadings of a direct relationship and specific interactions between the parties, plaintiffs' actions against governmental authorities will likely continue to fail, and be struck out in preliminary motions. ${ }^{37}$

By asking whether it was reasonably foreseeable that consumers or the industry would reasonably rely on the representations made.

Imperial Tobacco, supra note 3 at para 49.

It is unclear from the judgment whether the Court decided that despite the existence of reasonable and foreseeable reliance by consumers on the government's representations there was still no proximity, or whether in the absence of "direct interactions" between the parties there could not be reasonable and foreseeable reliance. In other words, in novel negligent statement cases must there be a "special relationship," as traditionally understood, plus "proximity”?

This is important; one rationale for allowing law suits to succeed against government regulators for their failure to prevent harm is that the public reasonably relies on government to protect them. Thus, the argument would be that because of reliance, the government is not subject to the common law principle that a person owes no duty to another to prevent harm from a cause unconnected to the defendant. By requiring "direct interactions" and rejecting general reliance to support a duty between government regulators and private persons, the Court has rejected that argument. 


\section{F. Policy Considerations Negating the Prima Facie Duty: THE Policy/OPERATIONAL Dichotomy}

Even where a prima facie duty exists, it can be negated or limited by policy considerations at the second stage of the refined duty test. In this respect, the "policy/operational" dichotomy is the principal concern of the courts in limiting the liability of public authorities at the residual policy stage of the duty analysis.

The policy/operational dichotomy has bedeviled Canadian courts ever since it was first articulated by the House of Lords in Anns and firmly adopted into Canadian law by the Supreme Court of Canada in Kamloops (City of) v. Nielsen. ${ }^{38}$ As I have written elsewhere, although the rationale of the dichotomy is easy to understand and seems sensible, it is difficult to apply. ${ }^{39}$ The theory is that if the impugned activity represents a "policy" decision taken by a public authority, it is immune from the ordinary negligence law duty of care. This is because courts, for reasons of both competence and capacity, are reluctant to second guess the policy decisions of public authorities. As long as the policy decision was made "in good faith" it is not subject to tort liability. If, on the other hand, the impugned conduct relates to "operations" (that is, the manner in which the policy decision was executed), it is subject to the regular duty of reasonable care.

Imperial Tobacco is at least the fourth time the Supreme Court of Canada has taken a serious look at the policy/operational dichotomy since it first adopted it in Nielsen. The first was in Just v. British Columbia. ${ }^{40}$ That case involved injury and death caused by a boulder that fell onto the plaintiff's car from a slope above a highway. The Province of British Columbia had put into place a system for monitoring the slopes to remove potential hazards. The issue was whether the province had been negligent in this instance and, if so, whether the plaintiffs could successfully sue.

One of the things interesting about Just is that the trial judge who wrote the judgment was Justice McLachlin (as she then was). ${ }^{41}$ In a relatively short judgment, Justice McLachlin held that the decisions taken by the crew with respect to the monitoring of the slopes fell within the area of policy and could not be reviewed by the Court. She conceded that the distinction between policy decisions and operational functions was a difficult one to draw. She identified four factors which are characteristic of policy decisions: they involve planning, they involve the allocation of scarce resources and balancing factors such as efficiency or thrift, they involve discretion, and there are no standards against which the conduct could be evaluated. Justice McLachlin also indicated that these decisions could be made by persons "working in the field." 42 Applying these factors to the case at hand, Justice McLachlin concluded that the way the rock monitoring crew went about its business, in terms of the number, quality, and

[1984] 2 SCR 2 [Nielsen].

In my text, Klar, Tort Law, supra note 23 at 308-11, I illustrate my concerns by reference to 28 judgments which applied the policy/operational dichotomy. In 15 of the judgments, the courts decided that the misconduct in issue related to policy decisions of public authorities. In 13 of the judgments, the misconduct was said to be related to the operational activities. It is difficult to distinguish many of these judgments and to decide on which side of the line the misconduct should have been placed.

[1989] 2 SCR 1228 [Just].

See Just v British Columbia, [1985] 5 WWR 570 (BCSC).

Ibid at 576. 
frequency of the measures that it adopted to monitor the slopes, was not a matter for the courts to review. The British Columbia Court of Appeal agreed. ${ }^{43}$ The Supreme Court of Canada, however, did not. Therein lies the interesting comparison to Imperial Tobacco.

The judgment in Just was written by Justice Cory, with Justice Sopinka dissenting. It is a somewhat difficult judgment to summarize and as I have attempted to do so elsewhere, ${ }^{44}$ I will not try again here. Suffice it to say that Justice Cory did not agree with Justice McLachlin's view of the matter. In the majority's opinion, the manner and quality of the defendant's inspection system fell clearly within the operational aspects of the governmental activity. By using a hypothetical example of lighthouse inspections, Justice Cory explained that, having established a policy to inspect lighthouses, "the court may review the scheme of inspection to ensure it is reasonable and has been reasonably carried out in light of all the circumstances, including the availability of funds, to determine whether the government agency has met the requisite standard of care.” ${ }^{~} 5$ The majority of the Court sent the case back to trial, and negligence was found. ${ }^{46}$

Justice Sopinka dissented in Just. His opinion was that the majority judgment "would considerably expand the liability for negligence of public authorities by subjecting to judicial review their policy decisions which were hitherto not reviewable." ${ }^{47}$ According to Justice Sopinka, policy decisions involve not only the question of whether to do something, but as well the time, manner, and technique of doing it. If it were otherwise, very little would be left to policy and most everything would be subject to review.

In my comment following Just, I agreed with Justice Sopinka's view that the majority judgment significantly extended the potential liability of public authorities. ${ }^{48}$ I suggested that Just had limited the policy aspects of governmental activities to the "threshold decisions alone." ${ }^{49}$ Although I thought that this could potentially be problematic, ${ }^{50}$ it at least had the advantage of having drawn a relatively clear boundary line between policy (threshold decisions) and everything else done in implementing that policy (operations).

This was not to be so. In two Supreme Court of Canada judgments after Just, namely Brown v. British Columbia (Minister of Transportation and Highways) ${ }^{51}$ and Swinamer v. Nova Scotia (A.G.), ${ }^{52}$ the Court, per Justice Cory, revisited what he had said in Just. ${ }^{53}$ The

See Just v British Columbia, [1987] 2 WWR 231 (BCCA). The judgment was very short, and did not provide its own reasons other than agreeing with Justice McLachlin.

See Lewis N Klar, "The Supreme Court of Canada: Extending the Tort Liability of Public Authorities," Case Comment on Just v British Columbia, (1990) 28:3 Alta L Rev 648 [Klar, “Tort Liability”]. Supra note 40 at 1243.

See Just v British Columbia, (1991), 60 BCLR (2d) 209 (SC). The trial judge held that the manner of inspecting the slopes was negligent.

Supra note 40 at 1250.

See Klar, "Tort Liability," supra note 44 at 655.

Ibid.

I anticipated an increase in cases brought against public authorities, requiring courts to review policy decisions made at the operational level for their reasonableness. I stated as well that it might encourage legislatures to include exemption clauses in their legislation to immunize public authorities against liability. I believe it is fair to say that both of these things happened.

[1994] 1 SCR 420 [Brown].

[1994] 1 SCR 445 [Swinamer].

I wrote about these cases as well: see Lewis Klar, "Case Comment: Falling Boulders, Falling Trees and Icy Highways: The Policy/Operational Test Revisited” (1994) 33:1 Alta L Rev 167. 
facts of Swinamer were similar to those in Just. This time a decayed tree fell from a slope above the highway onto the plaintiff's truck. The allegations of negligence related to the system that the Province of Nova Scotia had put into place to prevent such occurrences. Brown involved an icy highway and the system that the Province of British Columbia had put in place to salt and sand dangerous conditions on its roads.

The trial judge in Swinamer ${ }^{54}$ applied what he thought the Supreme Court of Canada had said in Just and held that the matter was one of operations. Significant portions from the judgment in Just were directly quoted. The province was found liable. The Court of Appeal reversed the trial judgment, although on grounds largely outside of the policy/operational dichotomy. ${ }^{55}$ The Supreme Court of Canada, per Justice Cory, also reversed the trial judgment and exonerated the province of liability. The judgment is somewhat obscure on the matter of the dividing line between policy and operations. In the end, my analysis is that the Court actually did review the way the province implemented its policy and found that it was not negligent.

In Brown, the trial judge exonerated the province of its liability. ${ }^{56}$ The Court of Appeal affirmed that decision. ${ }^{57}$ It was the way in which Justice Cory dealt with the policy/operational dichotomy at the Supreme Court that I found the most interesting aspect of the judgment. Justice Cory retreated from the position he seemed to have taken in Just: that the manner in which a program is implemented is always reviewable as a question of operations. In fact, Justice Cory expressly repudiated the argument that "policy decisions must be limited to so called threshold decisions, that is to say, broad initial decisions as to whether something will or will not be done." ${ }^{28}$ Justice Cory stated that "[t]his would be contrary to the principles set out in Just." ${ }^{59}$ Justice Cory further stated that policy decisions can be made by persons at all levels of authority. ${ }^{60}$ Thus, the decision taken by the governmental authority in Brown to have its crews on summer schedule for sanding the roads at the time of the incident was termed a policy decision, immune from ordinary negligence law review. It is interesting to note, however, that the manner in which the sanding was carried out under that summer schedule was subjected to negligence law review. The province was not held liable.

As indicated above, the Canadian jurisprudence concerning the policy/operational dichotomy following the Supreme Court decisions in Just, Brown, and Swinamer was very uneven and unpredictable. In the years following the Cooper and Edwards judgments, however, consideration of the dichotomy became much less frequent. This is because, as discussed before, plaintiffs were failing at stage one of the duty test (proximity), rarely

Swinamer v Nova Scotia (AG) (1991), 101 NSR (2d) 333 (SC).

See Swinamer v Nova Scotia (AG) (1992), 108 NSR (2d) 254 (CA).

See Brown v British Columbia (Minister of Transportation and Highways) (1989), 17 MVR (2d) 69 (BCSC).

See Brown v British Columbia (Minister of Transportation and Highways), [1992] 3 WWR 629 (BCCA).

Brown, supra note 51 at 442 . What I find interesting about this statement is that in my case comment on Just (Klar, “Tort Liability,” supra note 44 at 653) I wrote that "true” policy decisions "are what I may describe as 'threshold' decisions; they decide in general terms whether something will or will not be done.” Justice Cory obviously did not agree with that interpretation.

Brown, ibid.

Ibid. 
making it to stage two, where the dichotomy is considered. But the tobacco companies in Imperial Tobacco did make it to stage two. The policy/operational dichotomy was again before the Supreme Court. It was “déjà vu all over again,” with one major difference. This time Justice McLachlin, previously of the British Columbia Supreme Court, was Chief Justice McLachlin of the Supreme Court of Canada, and she now had the last word.

The Supreme Court held that the government owed the tobacco companies a prima facie duty of care based on foreseeability and proximity, with respect to the negligent misrepresentation claim and the negligent design claim. The government also owed the consumers a duty with respect to the negligent design claim. ${ }^{61}$ This brought the Court to the second stage of the duty test - the consideration of policy reasons to negate the duty. Two policy considerations were considered by Chief Justice McLachlin: the policy/operational dichotomy, and concerns about indeterminate liability.

Chief Justice McLachlin's discussion of the policy/operational dichotomy was extensive. In terms of the negligent misrepresentation claim, she narrowed the issue to the following question: did the representations which the government made to tobacco companies regarding the health benefits of low tar cigarettes fall into the category of policy, or were they a matter of operations?

As she did as the trial judge in Just, Chief Justice McLachlin conceded that " $[\mathrm{t}]$ he main difficulty with the policy/operational approach is that courts have found it notoriously difficult to decide whether a particular government decision falls on the policy or operational side of the line." 62 The distinction "does not work very well as a legal test." 63 After reviewing the approaches taken in England, where the policy/operational dichotomy has been abandoned as unworkable and elusive, ${ }^{64}$ Australia, ${ }^{65}$ and the United States, ${ }^{66}$ Chief Justice McLachlin proposed the following test for Canadian law.

First, she rejected the view that all "discretionary" decisions made by public authorities are matters of non-reviewable policy. This would be to cast the immunity too broadly. ${ }^{67}$ Second, she explained that protected policy was a "subset" of discretionary decisions. Only "true" or "core" policy decisions were protected. ${ }^{68}$ Third, Chief Justice McLachlin adopted the approach of the majority of the US Supreme Court in Gaubert in defining "true policy decisions" as "discretionary legislative or administrative decisions and conduct that are grounded in social, economic, and political considerations.” 69 They are "generally” made by "legislators or officers whose official responsibility requires them to assess and balance public policy considerations."70 The decision represents "a course or principle of action

There was no prima facie duty owed to tobacco companies for failing to warn, and no prima facie duty owed to consumers for negligent misrepresentation.

Imperial Tobacco, supra note 3 at para 78.

Ibid.

Chief Justice McLachlin cited Lord Hoffmann in Stovin v Wise, [1996] UKHL 15, [1996] 3 AC 923. Citing Sutherland Shire Council v Heyman (1985), 157 CLR 424 (HC) and Pyrenees Shire Council v Day, [1998] HCA 3, 192 CLR 330.

Referring to the Federal Tort Claims Act of 1946, 28 USC, and the cases of Dalehite v United States, 346 US 15 (1953) and United States v Gaubert, 499 US 315 (1991) [Gaubert].

Imperial Tobacco, supra note 3 at para 84.

Ibid at para 85 .

Ibid at para 87.

Ibid. 
adopted or proposed by a government." ${ }^{\text {71 }}$ Reiterating to some extent what she had written as the trial judge in Just, Justice McLachlin reaffirmed her view that "[t]he weighing of social, economic, and political considerations to arrive at a course or principle of action is the proper role of government, not the courts. ${ }^{, 72}$

Fourth, she stated that policy decisions are generally not made by employees working at the operational level, but this is not the decisive criterion. ${ }^{73}$ Fifth, Chief Justice McLachlin conceded that even with this test, there will be difficult cases, although she was of the view that "most government decisions that represent a course or principle of action based on a balancing of economic, social and political considerations will be readily identifiable." ${ }^{74}$

Applying this test to the facts of Imperial Tobacco, Chief Justice McLachlin held that the decision made by the government to encourage smokers to switch to low tar cigarettes because they were allegedly less harmful to their health was a policy decision adopted at the highest level in the Canadian government, and involved social and economic considerations. Thus, the representations made to consumers to this effect, even if inaccurate and negligently made, were "part and parcel" of this policy. The policy was to encourage smokers to switch; this could only be accomplished by making representations to them to do so. Thus, these representations were not subject to tort law liability.

The same argument about policy was accepted with respect to the allegations that the government had been negligent in designing the tobacco strain. The government had made a policy that smokers should switch to low tar cigarettes and it designed the tobacco strain. The decision to do so was a true policy decision. It was immune from tort law review.

Despite Chief Justice McLachlin's best efforts to clarify the policy/operational dichotomy, it is my assessment that she did not. Nothing was added to the discussion that courts did not previously understand about the nature of the dichotomy. It was always understood that policy involved considerations concerning the balancing of resources, thrift, and efficiency, and were essentially "political" decisions.

What I believe is important about the judgment in Imperial Tobacco is not how the dichotomy was explained, but how it was applied. Unlike in Just, where the Supreme Court per Justice Cory decided that once having made the decision to inspect the hills for boulders, the "manner and quality" of the inspection system was a matter of operations which could be reviewed, the Supreme Court in Imperial Tobacco decided that once having made the policy decision to encourage smokers to switch to low tar cigarettes, the way that the government went about this plan was also part of the policy decision. Thus, deciding on what types of representations should be made, what types of warnings should be given, and even

Ibid, citing the New Oxford Dictionary of English, 1st ed, sub verbo "policy."

Imperial Tobacco, ibid at para 87.

Ibid at para 89.

Ibid at para 90 . 
how the strain of tobacco should be designed and developed were core policy decisions immune from negligence law's scrutiny. ${ }^{75}$

It seems to me that the facts and issues in Just were similar to those in Imperial Tobacco. The Province of British Columbia had decided to implement a policy of monitoring hills for dangerous conditions, and had assigned the task of doing so to a crew. As Justice McLachlin herself held in Just when she approached the matter as a trial judge, once the policy decision to monitor slopes was made, the decisions made on how to implement this policy were also part of that non-reviewable policy. It was not for the courts to tell the government authorities how to monitor the slopes. The Supreme Court of Canada in Just disagreed with Justice McLachlin of the British Columbia Supreme Court. Chief Justice McLachlin of the Supreme Court of Canada now had the opportunity to revisit the issue. And she did so by effectively reaffirming the position that she had taken as the trial judge in Just. $^{76}$

Although it is impossible to know how future courts will interpret and apply Imperial Tobacco, of one thing I am certain: the judgment is a big win for public authorities. It extends significantly the policy aspects of governmental conduct, making it even more difficult for plaintiffs to succeed in these cases. ${ }^{77}$

\section{G. INDETERMINATE LIABILITY}

The second policy reason for denying the duty was indeterminate liability. Chief Justice McLachlin reasoned that since the government had no way of controlling the number of cigarettes being sold to consumers, it could not control the extent of its liability.

There was relatively little said by Chief Justice McLachlin about this issue of indeterminate liability, and I will not dwell on it here. Suffice it to say that I do not find this argument persuasive and do not think it should be a factor used to deny duties in any cases. Since Canadian law now requires both foreseeability and proximity to establish a presumptive duty, it is difficult to see how indeterminate liability can ever be a problem. Liability in negligence is never indeterminate. It is always determined and constrained by the elements of the negligence action; the need to establish a duty of care, breach of that duty, and foreseeable injuries. A duty is only found where it is "just and reasonable" to recognize

75 It is interesting to note the nature of the allegations made in the third party claims against the government in pursuit of its policy. The government's conduct involved publishing tables showing the tar and nicotine yields of cigarette brands and putting out press releases containing representations or advice to smokers. The third party claims alleged that the government was aware of the negative health consequence to smokers who switched, for example, if they smoked more cigarettes. The many activities conducted by the government in terms of their co-operation with and support for tobacco growers and cigarette manufacturers were described. In other words, not only the policy to encourage smokers to switch was considered protected, but all the activities and programs identified in the third party claims to implement this policy were also immune.

76 Chief Justice McLachlin did not refer to her own opinion in Just. It is interesting to speculate as to how today’s Supreme Court of Canada would decide Just in view of Imperial Tobacco.

Perhaps the fact that the third party claimants in Imperial Tobacco were tobacco companies trying to deflect their responsibilities for the injurious effects of smoking onto the Government of Canada influenced the way this case was decided. As well, one must keep in mind that the third party claims were not about governmental conduct which resulted in the death or serious personal injuries to the claimants, but the attempt by tobacco companies to recoup some of the economic losses they allegedly suffered as a result of government regulation. Had the claimants been more attractive and the injuries more serious, perhaps the claims would have fared better. 
one. It is true that liability in some cases can be extensive, but "extensive" liability is different from "indeterminate" liability, and although it might be of concern to legislators, ${ }^{78}$ it should not be of concern to the courts.

\section{ConClusion}

The judgment in Imperial Tobacco places even more restrictions on the ability of private persons to successfully sue public authorities for their negligent failures in three respects.

First, although the Supreme Court maintained its view that proximity between claimants and public authorities can be found in the statutory provisions which establish and empower the authorities, it conceded that it will be difficult for claimants to find proximity there. Statutes created for the protection of public goods cannot be interpreted to create private law remedies. Since most statutes fit that description, this leaves little left.

Second, although proximity between public authorities and private persons can be found in the relationships and interactions between them, there must have been "specific interactions" and a "direct relationship.” Merely relying and acting upon representations made by the government to the general public is insufficient to establish proximity.

Third, even if there is proximity, government is immune from negligence law liability if its conduct can be described as a "true" or "core" policy decision. In this respect, a core policy decision encompasses not only the decision to embark on a certain course or principle of action adopted by the government, but also the decisions and steps taken to further or implement that course of conduct. 